medicine and science. In December 1985 the centre held a weekend workshop which was called Persons and Values. This volume is a result of that workshop.

Many of the philosophical issues which surround the concepts of person and personality bear directly on matters of medical interest. Much of the debate about abortion, for example, is over the issue of 'When is a fetus a person?' Of more interest to me is the question of when psychological problems should be seen as part of the person, and when they should be seen as something alien. For example, depression can be viewed as a disease which 'attacks' a person, or alternatively as part of the personality. In my outpatient clinic I find myself moving uneasily between these two broad formulations with their differing therapeutic implications.

Psychotherapy and theology alike are interested in the question of how a person may be helped to become fulfilled. In both disciplines there is an implied difference between, on the one hand changing someone, and, on the other, helping him or her to develop.

In this volume there are thirteen essays by a range of people, for example, doctors, philosophers, lawyers, sociologists, theologians.

It is as though one had asked a number of different people to take a photograph of some aspect of Oxford and then placed all the photographs in one frame. There is no intellectually satisfying whole, but it is a fascinating book to sample, knowing only, as you start each essay, that it will give you one person's glance at one feature of the problems surrounding persons and personality.

R A HOPE

Department of Psychiatry, University of $\mathrm{Oxford}$

\section{Recollections and Reflections}

Douglas Black, 132 pages, London, £14.95, British Medical Journal, 1987, hbk

This an outstanding book by a very remarkable man. It is one of a series, The Memoir Club, commissioned by Dr Stephen Lock, editor of the British Medical Fournal. Though not strictly an autobiography it is rather a series of memories and reflections of a life in medicine, scholarship, research and administration.

The author begins with the framework - as a medical student at the University of St Andrews, as a resident - and then goes on to describe his years in Oxford. He went to Oxford originally to work with Leslie Witts, doing research into gastric haemorrhage, but this led onto work with burns. This was followed by work in Cambridge with Elsie Widdowson where his special interest in problems of fluid balance led to the study of nephrology, the medical aspect of disease of the kidneys.

War-time service with the Royal Army Medical Corps (RAMC) took him to West Africa and to India, eventually taking him to the Central Military Pathology Laboratory in Poona.

Returning to England he was appointed to a lectureship in Manchester; Robert Platt was then fulltime Professor of Medicine there. Somewhat to his surprise he stayed in Manchester for 26 years, succeeding Robert Platt as Professor of Medicine, and eventually as President of the Royal College of Physicians in London. He comments on the responsibilities of a professor of medicine, clinical care of patients, administration, examining and research. This last interest led Sir Douglas to membership of the Medical Research Council.

His chapter on medical practice reveals a doctor with great sympathy and feeling for patients and their relatives, even in the stress of a busy outpatient clinic. He notes the increasing specialisation in medicine with the problems this may bring and the virtual disappearance, at least in larger hospitals, of the 'general physician'.

The chapter on the progress of medicine asks the questions: Has there been an improvement in health? Has increase in medical knowledge contributed to it? Has access to health care improved? His answer to all these questions is a qualified 'yes'. In particular he deals with his own subject of nephrology, indicating the progress made by kidney dialysis and transplants. He finds that on the whole the National Health Service has been a success in spite of current underfunding and that it compares favourably with the system of health care in the USA.

The next chapter deals with his time in Manchester, with comments on medical examinations. He notes with pride the development of one of the earliest university departments of general practice under its first professor, Pat Byrne.

As a member of the Medical Research Council he became Chairman of the Clinical Research Board. This led, in
1973, to his relinquishing his chair in Manchester to become the Chief Scientist at the Department of Health. His time at the Department of Health and Social Security (DHSS) led to the publication of the famous Black Report on inequalities in health. This showed the health disadvantage suffered by manual workers, particularly unskilled, and the health disadvantages of social deprivation. He does maintain however that advances in curative medicine have done something to reduce mortality from diseases for which treatment is effective.

In 1977 Douglas Black succeeded Sir Cyril Clarke as President of the Royal College of Physicians in London, an office he held until 1983. He describes the function of the college and the many duties of the president, responsible as he is for the problems of physicians throughout England, Wales and Northern Ireland. The positive aim of the college is to maintain and improve the standards of practice in the interests of patients. In particular the colleges are concerned with postgraduate training. In Black's time many issues came up for consideration. These included tobacco, fluoride in water and nutritional topics such as dietary fibre, obesity and food intolerance. Of great public concern was the Panorama programme on brain death. Another matter was the possible association of nuclear emissions at Sellafield and childhood leukaemia; this latter is still uncertain.

After retirement he has found many activities. Through the Wellcome Trust he was able to convene a committee of the Royal College of Physicians on ethical aspects of medicine. While President of the Royal College of Physicians he accepted an invitation to become a consulting editor of this journal and subsequently he also became President of the Institute of Medical Ethics, which publishes the journal. He has also served as President of the Medical Protection Society which defends doctors accused of negligence and has an important role in all the medicolegal aspects of the practice of medicine. He then became President of the British Medical Association, the Medical Council on Alcoholism, and Health Concern.

These appointments were followed by the chairmanship of the British Medical Association's board of science and education. He chaired a working party on alternative medicine after Prince Charles, in his presidential address, had asked for consideration of the matter. It was decided that a controlled trial would be impracticable 
but emphasis was placed, by the working party, on the importance of correct diagnosis before any treatment is undertaken.

Another assignment he clearly enjoyed was a survey of health care in Guernsey.

His last chapter, entitled Questions without Answers, deals with ethical and medical practice. He concludes that doctors must maintain good standards of medical practice. Research must be based on sound ethical practice. In no sphere is this currently more important than in the current discussion of in vitro fertilisation and all that results from the new techniques of human reproduction, and Sir Douglas must be a valued member of the Voluntary Licensing Authority set up under the chairmanship of Dame Mary Donaldson by the Royal College of Obstetricians and Gynaecologists and the Medical Research Council. The deliberations of this authority will be invaluable when legislation on these difficult and contentious matters is debated in Parliament.

This is a fascinating and eminently readable account of a life spent in the service of medicine in its widest context. Douglas Black is never pompous and his writing is admirably economical of words. Like a field marshal's baton it should be in the knapsack of every medical student and young doctor, while those of more mature years will profit as I have, by the privilege of reading it and of knowing a truly great physician.

DAME JOSEPHINE BARNES Consulting Obstetrician and Gynaecologist

Charing Cross Hospital and Elizabeth Garrett Anderson Hospital 8 Aubrey Walk London W8

\section{Setting Limits: Medical Goals in an Aging Society}

Daniel Callahan, 256 pages, New York, $\$ 18.95$, Simon and Shuster, 1987
The author of this important book is director of the Hastings Center for the study of Medical Ethics in the United States. He has written on medical ethical topics such as abortion and 'medicated survival'.

In this book he addresses the issue of when and in what circumstances it is suitable to withhold the full panoply of modern medical technology from sick old people and comes down firmly in favour of applying only measures for relief of suffering and preservation of dignity for those who have become aged and who have led long and full lives.

He discusses in detail the arrogant assumptions which underlie the use of medical technology to prolong life in almost any circumstances and points out that when applied to very old people this destroys the very meaning of old age as a time of reflection and of help to younger generations which is characterised by an acceptance of death as a natural and desirable event when its time has come.

There is a useful discussion of the rights and obligations of generations within society and Burke is quoted: 'Society is a partnership not only between those who are living, but between those who are living, those who are dead and those who are to be born'. He maintains that society owes more to the young than to the old: 1) since the former have not asked to be born, and 2) since the old have in any case led full and long lives and may thus be prepared to leave this world.

\section{Dignity}

Modern medicine has enabled us to avoid or postpone death in a remarkable fashion, but its indiscriminate use in old age is to be deprecated since it not only squanders vast resources (hence not available for younger patients) but also distorts the true meaning and dignity of old age.

It is emphasised that while extraordinary measures directed solely at life prolongation are to be avoided in old age, it is essential that suffering must be relieved, expert nursing care must be freely available and family and other carers must always receive the fullest help and support. A plea is made for treatment of the patient as an individual, which is much more important than treatment of his or her organs. Excessive use of technology is cruel where 'life has become a blight rather than a blessing' and the author describes this use 'not, as some would have it, respect for age but an idolatrous enslavement to technology'.

At an early stage in this book it is stated that the author advocates withholding of medical technology (for life prolongation) above a certain age (late 70's, early 80's) and I became fascinated to find out how he was going to sustain this suggestion. However, on page 184 he retreats by stating that for the 'physically vigorous old person' all levels of care are appropriate. In other words, it is not age but 'physical vigour' which must determine our response. $N$ Unfortunately we are not in a good 윽 position to judge this since it is dependent upon reserve function, and $\Theta$ we have only imperfect ways of $\frac{\mathbb{D}}{D}$ measuring this. Thus we fall back upon 'clinical judgement' with all its imprecisions and deficiencies.

\section{Perspicacity}

It is of more than passing interest the the author compares the British syste very favourably with the American. has been possible in the UK 'to break the monopoly of high-technology medicine and the endless struggle against aging and death that has been its most willing partner'. With remarkable perspicacity, the author warns us against our current trend towards 'recreation of a private health care system' which steers medicine in the US direction.

I would have dearly liked to comment upon the sections which deal with euthanasia (easily dismissed) and the withholding of antibiotics, fluid and food (competently supported) but space does not permit.

Doctors and nurses should read this $I$ book, as should thinking laymen and politicians.

PROF J WILLIAMSON N 14 Ann Street 요 Edinburgh $\omega$ EH4 1PF 